\title{
Blasts Under 25 Percent of Bone Marrow Nucleated Cells
}

National Cancer Institute

\section{Source}

National Cancer Institute. Blasts Under 25 Percent of Bone Marrow Nucleated Cells. NCI

Thesaurus. Code C137701.

A semi-quantitative microscopic finding indicating that less than 25 percent of the nucleated cells in a bone marrow sample are immature mononuclear cells. 